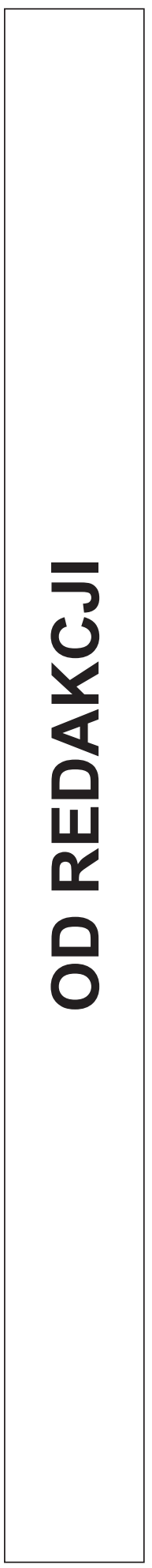





\section{SLOWO WSTĘPNE}

$\mathrm{Z}$ dużą przyjemnością prezentuję Państwu drugi numer czasopisma „Przegląd Strategiczny”. Mam nadzieję, że podobnie jak numer pierwszy, spotka się z życzliwym przyjęciem środowiska naukowego oraz innych osób zainteresowanych problematyką bezpieczeństwa, geopolityką czy stosunkami międzynarodowymi. Tak samo, jak w przypadku pierwszego numeru abstrakty oraz wybrane artykuły zostaną opublikowane na stronie internetowej http://studiastrategiczne.amu.edu.pl. Zapraszamy zatem do lektury czasopisma zarówno $\mathrm{w}$ wersji papierowej, jak i elektronicznej.

Nowością w numerze drugim jest zamieszczenie, zgodnie z wcześniejszą zapowiedzią, nowych działów: Bezpieczeństwo militarne oraz Bezpieczeństwo energetyczne. Problematyka ta będzie także poruszana w przyszłości.

W numerze trzecim „Przeglądu Strategicznego” planujemy zamieścić ponadto wybrane wystapienia wygłoszone podczas panelu naukowego zatytułowanego „Liberalizm i wojna", który odbył się na Wydziale Nauk Politycznych i Dziennikarstwa (WNPiD) UAM pod koniec października 2011 roku. Został on zorganizowany przez Stowarzyszenie Projekt Polska, European Liberation Forum oraz Zakład Studiów Strategicznych WNPiD. W dyskusji udział wzięli m.in.: przedstawiciel Ministerstwa Obrony Narodowej, pracownicy naukowi oraz eksperci zajmujący się bezpieczeństwem.

Kolejną inicjatywą naukową, która znajdzie swoje odzwierciedlenie na łamach trzeciego numeru czasopisma jest międzynarodowa konferencja „Poza oblężoną twierdzę. Interdyscyplinarność w nauce o stosunkach międzynarodowych”. Odbyła się ona na Wydziale Nauk Politycznych i Dziennikarstwa w listopadzie 2011 roku i zgromadziła ponad 50 specjalistów reprezentujących kilkanaście ośrodków naukowych, w których prowadzone są badania nad istotą oraz ewolucją współczesnych stosunków międzynarodowych. Konferencja oprócz sesji plenarnej obejmowała sześć paneli tematycznych:

- O interdyscyplinarności nauki o stosunkach międzynarodowych;

- Granice i przedmiot nauki o stosunkach międzynarodowych;

- Ekonomia a nauka o stosunkach międzynarodowych;

- Metody i podejścia w badaniu stosunków międzynarodowych;

- Studia regionalne;

- Stosunki międzynarodowe a inne dyscypliny.

Konferencja została zorganizowana przez Wydział Nauk Politycznych i Dziennikarstwa UAM, Polskie Towarzystwo Studiów Międzynarodowych, Polskie Towarzystwo Studiów Międzynarodowych Oddział w Poznaniu oraz Zakład Studiów Strategicznych WNPiD UAM. Patronat medialny sprawowało Radio Merkuty - Polskie Radio. Szczegółowy program konferencji dostępny jest na stronach: http://studiastrategiczne.amu.edu.pl oraz http://wnpid.amu.edu.pl. 
Czwarty numer czasopisma planujemy wydać w całości w języku angielskim. Będzie on dotyczyć kluczowych problemów oraz wyzwań występujących na świecie na początku XXI wieku, a mających wymiar polityczny, ekonomiczny i społeczny. Zapraszam do nadsyłania drogą mailową (studiastrategiczne@amu.edu.pl) tekstów oraz recenzji poświęconych powyższej problematyce, w terminie do 30 września 2012 roku.

Wojciech Roszkowski, pisząc na temat nacjonalizmu, posłużył się stwierdzeniem, że jest to „stare wino w nowych butelkach”, a zatem dotyczy od dawna występującego problemu, który wciąż przybiera nowe formy. Powyższe sformułowanie ma jednak wydźwięk uniwersalny, albowiem zastosować je można także wobec wielu innych zagrożeń dla bezpieczeństwa, w tym i tych analizowanych $\mathrm{w}$ drugim numerze czasopisma. Zwraca ono ponadto uwagę na cztery bardzo istotne kwestie (jest to tzw. mechanizm czworokątny). Po pierwsze, wskazuje na głębokie korzenie historyczne i ponadczasowość występujących zagrożeń. Po drugie, podkreśla, że ciaggle ulegają one większym lub mniejszym przemianom, które są efektem oddziaływania zarówno czynników wewnętrznych (np. lokalnych determinantów ekonomicznych czy społecznych), ale zależą również od czynników zewnętrznych (choćby sytuacji międzynarodowej). Po trzecie, zagrożenia te związane są z różnego rodzaju innymi procesami czy zjawiskami. Wśród nich wymienić można m.in.: kryzysy finansowe, wojny i konflikty, globalizację, integrację regionalną, uwarunkowania geopolityczne itp. Po czwarte zaś, przytoczona przez W. Roszkowskiego fraza zwraca uwagę na liczne podobieństwa występujące między poszczególnymi zagrożeniami z zakresu bezpieczeństwa, np. między terroryzmem a fundamentalizmem islamskim.

Rozpatrywanym zagrożeniom oraz problemom występującym we współczesnych stosunkach międzynarodowych nie można przeciwdziałać tylko przy pomocy siły. Wskazuje na to choćby Henry Kissinger stwierdzając: „wobec pokonanego wroga - zwycięzcy, planując układ pokojowy muszą znaleźć drogę prowadzącą od nieprzejednania koniecznego dla zwycięzców, do pojednania, bez którego nie można osiagnąć trwałego pokoju" ". Z kolei Jeffrey Sachs ${ }^{2}$ podkreśla znaczenie tzw. weapons of mass salvation (broni masowego zbawienia), która może obejmować np.: przekazywanie lekarstw, odbudowanie czy wybudowanie szkoły, wiercenie studni głębinowych itp.

W tym kontekście przytoczyć jednak należy stare chińskie przysłowie, które głosi: „Nie sztuka pomagać. Ważne by pomagać skutecznie”. Jego trafności dowodzą m.in. przypadki udzielania pomocy humanitarnej, które, jak ocenił w jednym z swoich raportów Międzynarodowy Fundusz Walutowy, nie przyczyniły się do wzrostu gospodarczego w żadnym $\mathrm{z}$ analizowanych państw. Jeszcze bardziej krytycznie ocenił to zambijski ekonomista Dambisa Moyo: „Pomoc humanitarna nie działa, nie działa

H. Kissinger, Dyplomacja, Warszawa 1994, s. 142.

J. Sachs, Weapons of Mass Salvation, „The Economist”, 26.10.2002. 
i nigdy nie będzie działać. Nie rozwiąże żadnych problemów - to ona stanowi problem"³. Jest to niewątpliwie teza kontrowersyjna. Jej rozszerzenie znajdą Państwo m.in. w książce Lindy Polman Karawana kryzysu. Za kulisami przemystu pomocy humanitarnej (2011). Zachęcam zatem do lektury, a przede wszystkim refleksji nad wskazaną książką i drugim numerem czasopisma.

Sebastian Wojciechowski Redaktor naczelny

3 J. Nikodemska, Humanitarny skandal, „Fokus. Poznać i zrozumieć świat”, 09.2011. 
